\title{
REVISED Cancer T-cell therapy: building the foundation for a
}

\section{cure [version 2; peer review: 3 approved]}

\section{Alexander Kamb (D), William Y. Go}

A2 Biotherapeutics, Agoura Hills, California, 91301, USA

V2 First published: 03 Nov 2020, 9:1295

https://doi.org/10.12688/f1000research.27217.1

Latest published: 22 Dec 2020, 9:1295

https://doi.org/10.12688/f1000research.27217.2

\section{Abstract}

T-cell cancer therapy is a clinical field flush with opportunity. It is part of the revolution in immuno-oncology, most apparent in the dramatic clinical success of PD-1/CTLA-4 antibodies and chimeric antigen receptor T-cells (CAR-Ts) to cure certain melanomas and lymphomas, respectively. Therapeutics based on T cells ultimately hold more promise because of their capacity to carry out complex behaviors and their ease of modification via genetic engineering. But to overcome the substantial obstacles of effective solid-tumor treatment, T-cell therapy must access novel molecular targets or exploit existing ones in new ways. As always, tumor selectivity is the key. T-cell therapy has the potential to address target opportunities afforded by its own unique capacity for signal integration and high sensitivity. With a history of breathtaking innovation, the scientific foundation for the cellular modality has often been bypassed in favor of rapid advance in the clinic. This situation is changing, as the mechanistic basis for activity of CAR-Ts and TCR-Ts is backfilled by painstaking, systematic experiments-harking back to last century's evolution and maturation of the small-molecule drug discovery field. We believe this trend must continue for T-cell therapy to reach its enormous potential. We support an approach that integrates sound reductionist scientific principles with well-informed, thorough preclinical and translational clinical experiments.

Keywords

CAR, TCR, cancer, mechanism of action, clinical translation, innovation

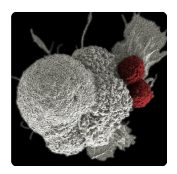

This article is included in the Oncology

gateway.

\section{Open Peer Review \\ Approval Status \\ 12 \\ 23 \\ version 2 \\ (revision) \\ 22 Dec 2020 \\ version 1 \\ 03 Nov 2020

$\begin{array}{cc} & \\ \text { view } & \text { view } \\ ? & ? \\ \text { view } & \text { view }\end{array}$

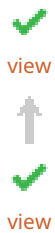 \\ 1. John R. James ID, University of Warwick, Coventry, UK \\ Muna Fuyal (D), University of Warwick, \\ Coventry, UK \\ 2. Barbra J. Sasu iD, Allogene Therapeutics, \\ Inc.,, San Francisco, USA}

3. C. Glenn Begley, BioCurate, Parkville,

Australia

Any reports and responses or comments on the article can be found at the end of the article. 
$\Delta$ This article is included in the Preclinical

Reproducibility and Robustness gateway.

Corresponding author: Alexander Kamb (akamb@a2bio.com)

Author roles: Kamb A: Writing - Original Draft Preparation; Go WY: Writing - Review \& Editing

Competing interests: Both authors (Kamb and Go) are employees and shareholders of A2 Biotherapeutics.com.

Grant information: This work was supported by A2 Biotherapeutics, Inc.

The funders had no role in study design, data collection and analysis, decision to publish, or preparation of the manuscript.

Copyright: ( $) 2020$ Kamb A and Go WY. This is an open access article distributed under the terms of the Creative Commons Attribution License, which permits unrestricted use, distribution, and reproduction in any medium, provided the original work is properly cited.

How to cite this article: Kamb A and Go WY. Cancer T-cell therapy: building the foundation for a cure [version 2; peer review: 3 approved] F1000Research 2020, 9:1295 https://doi.org/10.12688/f1000research.27217.2

First published: 03 Nov 2020, 9:1295 https://doi.org/10.12688/f1000research.27217.1 


\section{REVISED Amendments from Version 1}

We thank the reviewers for their constructive comments and believe they have understood our key point: the need for funding agencies/departments to invest in foundational understanding of T-cell therapy, including preclinical mechanistic work. We point out that we intend our paper to be an opinion or perspective, and not a review. Consequently, we have limited some of the references and discussion.

Any further responses from the reviewers can be found at the end of the article

If you have built castles in the air, your work need not be lost; that is where they should be. Now put the foundations under them.

\section{Henry David Thoreau, Walden 1854}

\section{T-cell therapies are the future of oncology}

It is astounding how the contents of the typical pharmacy have changed over the last 100 years. A century ago, pharmacists stocked their shelves with aspirin, opiates, mercury, arsenic, magnesium sulfate, iodine and a few other substances of legitimate medical value (Pharmacopoeia of the US, 1907). Since then, hundreds of small-molecule drugs, dozens of recombinant antibodies, and even a few nucleic acid therapeutics have been proven by rigorous scientific and clinical studies to treat a wide variety of human ailments. It is likely, however, that for a large number of patients yet to enjoy effective remedies for their disease, including cancer, cell therapy will ultimately provide the solution.

This prediction follows from the inherent strengths of cells as therapeutic entities. $\mathrm{T}$ cells, for example, are honed by evolution to execute numerous complex biological functions, among them identification and elimination of infected or damaged tissue (Janeway et al., 1999). They have tremendous natural advantage over other therapeutic modalities that are often limited to a single activity: binding to other molecules. Simple binding behavior may be sufficient to trigger salutary physiological changes and, indeed, there are many examples. However, the limitations imposed by having only hundreds of atoms like small molecules, or even thousands like antibodies, is evident. T cells, on the other hand, are composed of thousands of different molecules, prewired by evolution to work in concert to accomplish tasks of extraordinary complexity (Janeway et al., 1999). Specific killing is one of the simpler cellular behaviors, and is therefore among the first successful achievements of T-cell therapy, exemplified by three CD19-targeting chimeric antigen receptor T-cells (CAR-T cells) registered or close to registration (Abramson, 2020; Neelapu et al., 2017; Neelapu et al., 2020a; Schuster et al., 2019). The next frontier for engineered T-cell therapy is solid tumors, which pose additional challenges. Perhaps most dramatically, infused T-cell therapeutics directed against solid tumors must extravasate to reach their targets, targets that may be present on a subset of vital normal tissues as well. But cells have a second huge advantage as a therapeutic option: they can be readily manipulated with genetic alterations to augment or suppress their natural behaviors. The methods to do this are now routine and are improving with the advent of newer technologies such as CRISPR/Cas9 (Cong et al., 2013; Jinek et al., 2012). Combined with cellular reprogramming technologies, the possibilities to modulate natural cell properties or even create emergent ones are wide open (Takahashi \& Yamanaka, 2006; Yu et al., 2007). T cells are naturally endowed with the attributes of (i) outstanding sensitivity, able to detect a handful of molecules on a cell surface; (ii) multivariate signal integration, permitting them to react to different environments and discriminate among a variety of cell types; and, (iii) the capacity to proliferate. These traits are exactly those needed to overcome obstacles posed by solid tumor therapy.

We need to build a robust mechanistic foundation

To overcome the obstacles to solid tumor therapy, we must first recognize certain facts. A hallmark of the T-cell therapy field is striking innovation, with towering figures such as S.A. Rosenberg who has spent 40 years spearheading the clinical use of $\mathrm{T}$ cells in cancer (Fisher et al., 1989; Yron et al., 1980). Others, including G. Gross and Z. Eshhar (CAR), M.R. Roberts and M.H. Finer (Gen2 CAR), and V.D. Fedorov and M. Sadelain (iCAR) have designed robust novel receptors that can substitute for, or extend, T-cell receptor (TCR) function (Fedorov et al., 2013; Gross et al., 1989; Roberts et al., 1994). Still others have made substantive contributions to understanding, design and development of next-generation CAR-Ts; for example, C. June and P. Greenberg (see for review Guedan et al., 2019).

Notwithstanding the innovation and clinical success, the field lacks a strong foundation of mechanistic understanding. For example, there is not a broadly accepted model that explains key behavior of TCRs with respect to sensitivity and selectivity toward their ligands, peptide major histocompatibility complexes (pMHCs). CAR signaling, though understood in outline, also lacks important details (see for review Courtney et al., 2018; Nerreter et al., 2019). These gaps impede progress in areas that need to be addressed so that solid tumors can reliably and predictably be treated. It is instructive to draw an analogy with small-molecule drug discovery, a field that developed over the $20^{\text {th }}$ century from rudimentary industrial processes to a highly sophisticated discipline of quantitative structure-activity relationships based on structural chemistry, computational modeling, and pharmacodynamic analysis in vitro and in vivo (Figure 1).

As an emerging field, engineered T-cell therapy is not on a similarly solid footing. The standard suite of in vitro assays is crude when compared to those used in modern small-molecule or antibody optimization laboratories. Assays that vary effector:target ratios are convenient, but have high background and poor dynamic range. They are typically insensitive and subject to conflation of important biological variables; for instance, $\mathrm{T}$ cell proliferation and cytotoxicity as well as target-cell proliferation over time (Rossi et al., 2018). 


\section{Small-molecule therapeutic}

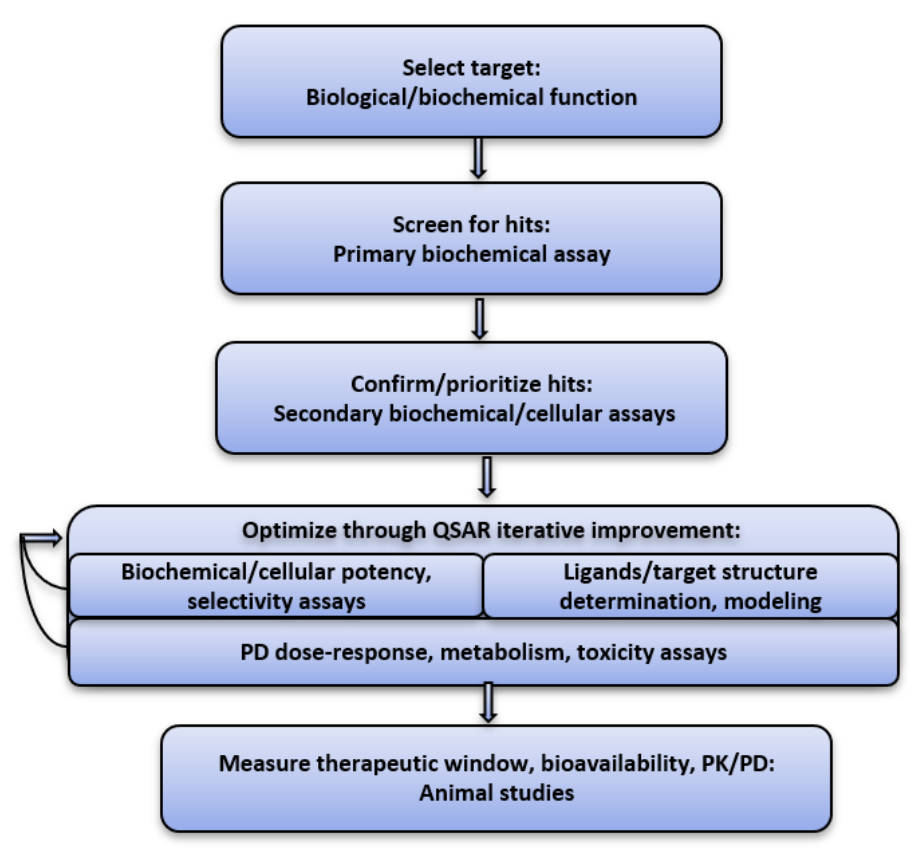

\section{$\underline{\text { T-cell therapeutic }}$}

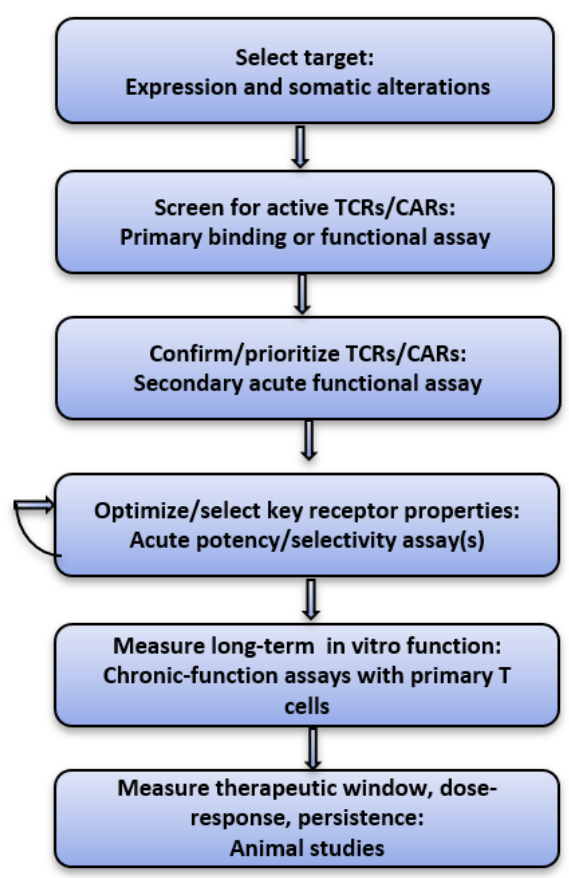

Figure 1. Flow scheme of drug discovery, comparing small-molecule to T-cell therapeutic discovery. QSAR, quantitative structure-activity relationship. The goal is to control variables and improve the predictability of substantive advances.

Primary human $\mathrm{T}$ cells are heterogeneous and cumbersome to grow, with considerable donor-to-donor variability; and the relationship between them and model cell lines, such as Jurkat, is not well understood (Salter \& Creswell, 1986). Murine cancer models must also trade off tractability with relevance, and have some obvious prima facie weaknesses. Assays of therapeutic efficacy and safety in murine models are notoriously unpredictive for clinical behavior (Kamb, 2005). These deficits apply to small- and large-molecule therapeutic discovery. In immuno-oncology specifically, even the best models use syngeneic grafts that do not originate in the host and, though matched at MHC, contain hundreds of nonsynonymous mutations and elicit immune response'. Many experiments employ chimeric murine models with a complicated mixture of murine and human immune components (e.g., humanized murine models, patient-derived xenografts). The human and mouse components of these chimeras, e.g., IL-2 and IL-2R, do not mesh perfectly (Nemoto et al., 1995). These models have utility and are chosen for practical reasons, but they are often regarded as decisive in selection of clinical

\footnotetext{
${ }^{1}$ https://www.criver.com/sites/default/files/resources/Whole-ExomeSomaticMutationAnalysisofMouseCancerModelsandImplicationsforPreclinicalImmunomodulatoryDrugDevelopment.pdf.
}

candidates because of presumptive experimental supremacy. In our view this is specious. The ultimate destination of a clinical candidate is the complex milieu of the human body and specifically the tumor microenvironment. But understanding the steps that must occur, one by one, to achieve a successful outcome in the clinic should not be dismissed as irrelevant just because they are studied outside the system biology of a human body. In vivo experiments should be used and interpreted judiciously in the context of robust in vitro data. As a T-cell therapy example, simple xenograft models demonstrate that therapeutic function is compatible with the environment of a mammalian body; nothing more, but nothing less.

Referencing small-molecule discovery again, the most successful efforts have involved deliberate construction of a mechanistic picture; from biochemical assays, through cell-based assays, to cautiously interpreted in vivo testing of pharmacodynamics. A clear example is the history of imatinib's discovery (Buchdunger et al., 1996). T-cell therapy would benefit from adoption of this approach to control as many of the variables as possible within a reasonable timeframe of drug discovery. Only then can the predictability of the discovery process improve to the point needed to address the challenges of solid tumor therapy. If we wish to continue to innovate and 
not settle for incremental advances to CD19-directed therapies where there are currently hundreds of ongoing clinical trials for an unmet need, now estimated at $~ 6,000$ deaths/year in the US, we must improve the mechanistic understanding and economical testing of candidate therapeutics. Otherwise, the opportunity costs will be enormous.

\section{The acute shortage of solid-tumor drug targets: targeting genetic gains and losses}

Selectivity is the supreme challenge of oncology. At the genetic level, a tumor differs on average at $\sim 10,000$ nucleotide positions from the normal tissues from which it arose-less than $0.01 \%$ of the human genome (Vogelstein et al., 2013). In contrast, siblings differ by about 10 million nucleotides. Perhaps even worse from a conventional therapeutic perspective, very few of these genetic changes are shared among a significant percentage of cancers. Only a handful of mutations, such as mutant KRAS and P53, occur at frequencies above 5\% of cancers. The vast majority are private mutations unique to each tumor. For decades, drug discoverers have searched for "magic bullets" that can discriminate reliably among tumor and normal cells, with some success. Good examples include imatinib for chronic myeloid leukemia, which inhibits the Abl kinase, and rituximab, a CD20 antibody that mediates the destruction of B-cell lineage cells such as non-Hodgkin lymphoma (Anderson et al., 1997; Buchdunger et al., 1996). Both these medicines are extremely effective within the subset of cancers they are designed to treat. In solid tumors, there are a few proteins, known loosely as tumor-selective antigens, whose expression is sufficiently limited in adult normal tissues that they continue to attract attention as possible cancer targets. These include CEA, MSLN, PSMA, and the MAGE family members (Lu et al., 2017; Parkhurst et al., 2011).

In 2001 the complete human gene list of $\sim 20,000$ was defined, establishing a boundary for new discoveries. Cancer researchers have scoured this gene set for the last two decades with diminishing success, visible in the shrinking, overlapping group of cancer targets swarmed by academic research laboratories and pharma/biotech industry $R \& D$ organizations. We desperately need new options; and these will likely require utilization of known gene products in novel ways. Immuno-oncology offers prospects for doing so. The large majority of recurrent somatic mutations affect proteins expressed inside cells. Thus, it is necessary to overcome the barrier of the cell membrane that excludes antibodies and most other macromolecules to exploit somatic mutations as a source of selective cancer targets. The immune system has evolved the means to do so through the aegis of antigen presentation. Molecular complexes of major histocompatibility antigens bound to peptides derived from cellular proteins (pMHCs) give $\mathrm{T}$ cells a view of the internal contents of cells. Some of these pMHCs are likely the basis for PD-1 antibodies' and tumor infiltrating lymphocytes' (TILs) remarkable power to trigger tumor-specific killing by the immune system (Chamoto et al., 2020; Hinrichs \& Rosenberg, 2014). pMHCs that contain mutant peptides are currently the intended targets for numerous investigational vaccines and T-cell therapy efforts to engineer or select neoantigen-reactive $\mathrm{T}$ cells (Castle et al., 2019; Ng et al., 2019). The small number of recurrent mutations constrain the target options on this front. Though there are dozens-even hundreds-more private neoantigens, therapeutic exploitation of these via $\mathrm{T}$ cell engineering presents other challenges (Ng et al., 2019).

Loss of genetic material, rather than gain of somatic mutations, represents another opportunity to achieve absolute discrimination at the genetic level between tumor and normal cells. The most common form of genetic loss in cancer is loss of heterozygosity (LOH). An astonishing $20 \%$ of the genome in a typical cancer cell exhibits $\mathrm{LOH}$. These $\mathrm{LOH}$ regions include loci that encode polymorphic surface antigens that can be recognized by $\mathrm{T}$ cells. Genetic loss is irrevocable and furnishes a basis for discrimination, provided a method can be devised to take advantage of $\mathrm{LOH}$. The workings of a primordial branch of the immune system show the way. Natural killer (NK) cells, which evolved before the adaptive immune system, employ a system of signal integration that differentiates self from non-self by combining inputs from families of activating and inhibitory receptors (Bryceson \& Long, 2008). The logic of the NK system has been reproduced in an artificial circuit involving CARs (Fedorov et al., 2013). Versions of this basic circuit are capable in principle of utilizing $\mathrm{LOH}$ as a black-and-white difference between tumor and normal cells (Hamburger et al., 2020). Other approaches are under study, including transcriptional logic circuits and receptor masking (Desnoyers et al., 2013; Roybal et al., 2016). These attempts to widen the target source for selective cancer targets to other targets, including neoantigens and $\mathrm{LOH}$, are in their early stages, but they hold promise to dramatically increase the therapeutic options available for solid tumor patients.

\section{Additional challenges for T-cell therapy}

The justifiable excitement around cancer T-cell therapy must be balanced with acknowledgement that many significant challenges remain beyond tumor-selective targeting. Difficulties in T-cell manufacturing and delivery to patients translate into high production costs and time-delays (Fiorenza et al., 2020; Locke et al., 2020). Despite the technical hurdles, we view these issues as solvable through the iterative improvement cycles that are part of the standard practice of engineers. Efforts to automate, miniaturize and accelerate the production of autologous cells are underway (Castella et al., 2020). The opportunity to improve efficiency seems extremely attractive because the current doses of $\mathrm{T}$ cells range from 100 million to 100 billion cells-well beyond the number involved in a typical immune response in the body (Gudmundsdottir et al., 1999). Meanwhile, production methods for off-the-shelf allogeneic cell products have demonstrated early clinical success (Neelapu et al., 2020b).

Perhaps more significant, efficacy to date in solid tumors is unimpressive and safety issues, either off- or on-target, continue 
to plague clinical programs ( $\mathrm{Lu}$ et al., 2017; Norberg et al., 2020; Parkhurst et al., 2011). We believe these problems are also solvable. They will be addressed by biological solutions, as they are not generally the result of limits imposed by laws of physics and chemistry which constrain more mature modalities. Indeed, there are a myriad of levers to pull to improve T-cell therapy outcomes. In some respects, the opportunity set for improved design of T-cell therapeutics is so large, that the challenge is to prioritize and test the possibilities efficiently.

\section{An approach to future T-cell therapeutic discovery} We do not subscribe to the common view that human testing always trumps preclinical data, not because it is false in concept, but because it is problematic in practice. Variation in the clinic is typically large, the number of observations small, the expense high and timelines long (Locke et al., 2020; Silbert et al., 2019). We believe that well-designed preclinical experiments, interpreted within a solid framework of pharmacology and biology, will greatly aid analysis of clinical results, and in the long run support translational innovation that saves lives.

To this end, we propose a roadmap that begins by reducing the problem of solid tumor cell therapy into its components (Figure 2). These components incorporate essential requirements for solid tumor cell therapy to achieve efficacy and safety, including that the engineered cells must: (i) survive in the body post infusion; (ii) migrate through the body's tissues into the tumor microenvironment; (iii) overcome the potentially anti-inflammatory environment of the tumor; (iv) specifically recognize the tumor cells in a vast excess of normal cells; and, (iv) deliver a sustained cytotoxic blow sufficient to remove most, if not all, of the tumor bulk. These component activities can be parsed into scientific disciplines of biochemistry, pharmacology, cell biology, immunology, and tissue/organismal physiology.

There are many potential differences between, for example, TCRs and CARs which have not been tested systematically, and the field would benefit from their thorough examination (Table 1). It would be useful to have sufficiently large datasets to delineate the connection between tractable models and the more complicated preclinical systems, and ultimately, the clinic. In particular, we believe that quantitative assays that measure absolute sensitivity of receptors should be more widely employed, allowing direct comparisons among different targets and receptors. The collective time and expense on the one hand, and risk of irrelevant or non-robust results on the other, create significant overhangs for the field. Effort should be directed toward providing clear evidence to connect receptor properties to function, and $\mathrm{T}$ cell lines to primary cells. Given the potential importance of long-term survival and function of $\mathrm{T}$ cells for curative treatment of solid tumors, there is a pressing need for plausible in vitro models of chronic $\mathrm{T}$ cell activity. It is impractical to funnel large numbers of candidate receptors through in vivo models. This foundation-building work may not be glamorous, but is of great consequence and should be valued by scientific journals. Our strong view is that granting agencies should invest in foundation-building academic research, in part because shorter-term translational work is often attractive to the private sector. If the field as a whole invests to build the infrastructure and expertise of better preclinical models and larger

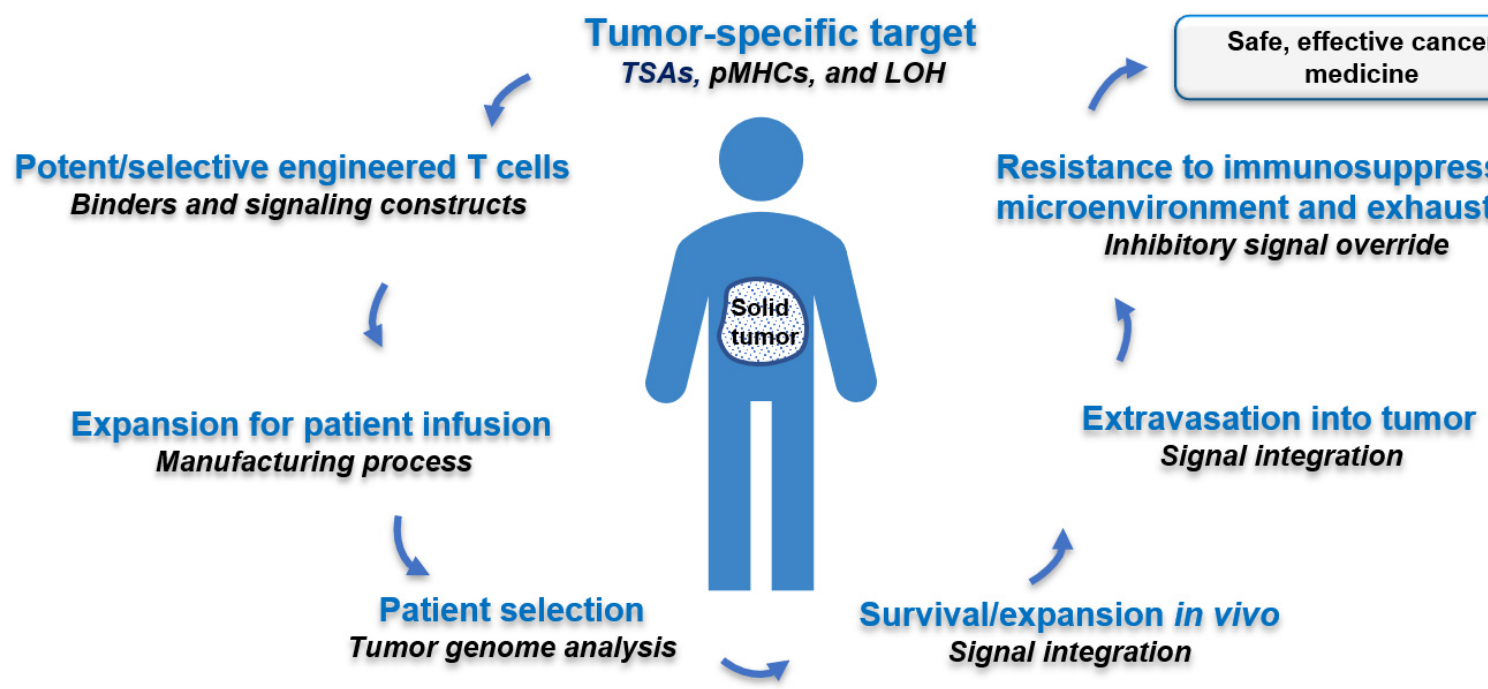

Figure 2. Cell therapy for solid tumors: step-wise requirements for success. This diagram illustrates the number and complexity of the steps required to achieve efficacy. Many of these steps can be studied in vitro; for others (e.g., extravasation), in vitro models are inherently problematic. TSA, Tumor Specific Antigen; pMHC, peptide-major histocompatibility antigen; LOH, loss of heterozygosity. 


\begin{tabular}{|c|c|c|c|}
\hline Molecule & Specific attribute & Assumption & Basis \\
\hline \multirow{2}{*}{ Target } & $\begin{array}{l}\text { High tumor expression of } \\
\text { target }\end{array}$ & Efficacy advantage & $\begin{array}{l}\text { Higher density increases activation } \\
\text { probability }\end{array}$ \\
\hline & $\begin{array}{l}\text { Solid tissue expression of } \\
\text { target }\end{array}$ & $\begin{array}{l}\text { Safety/tolerability } \\
\text { challenge }\end{array}$ & $\begin{array}{l}\text { No mechanism for tumor/normal } \\
\text { discrimination }\end{array}$ \\
\hline \multirow{8}{*}{$\begin{array}{l}\text { Receptor } \\
\text { (CAR and } \\
\text { TCR) }\end{array}$} & $\begin{array}{l}\text { Avidity correlation with } \\
\text { function }\end{array}$ & CAR $>$ TCR & $\begin{array}{l}\text { TCR known to have disconnects (e.g., pMHC } \\
\text { antagonism) }\end{array}$ \\
\hline & Target flexibility & CAR $>$ TCR & $\begin{array}{l}\text { TCR uses only pMHCs; CAR can target surface } \\
\text { antigens and pMHCs }\end{array}$ \\
\hline & Sensitivity & TCR $>>C A R$ & $\begin{array}{l}\text { TCR at the limit of sensitivity } \\
(1-10 \text { pMHCs })\end{array}$ \\
\hline & Selectivity & TCR $>>C A R$ & TCR evolves in body \\
\hline & $\begin{array}{l}\text { Tractable molecular } \\
\text { engineering }\end{array}$ & CAR $>$ TCR & TCR structure highly constrained \\
\hline & $\begin{array}{l}\text { Co-stimulation } \\
\text { independence }\end{array}$ & CAR $>$ TCR & Required for TCR activation \\
\hline & Checkpoint resistance & CAR $>$ TCR & $\begin{array}{l}\text { TCR sensitive; e.g., PD-1 mAb therapeutic } \\
\text { benefit }\end{array}$ \\
\hline & Exhaustion susceptibility & CAR $<$ TCR & CAR short-circuits regulators \\
\hline
\end{tabular}

datasets, and allocates time to define key mechanistic details prior to clinical testing, we believe the risks required to develop inventive, differentiated therapies will be rewarded with success.

\section{Conclusion}

The head of Novartis' drug discovery organization, J. Bradner, reportedly expressed the opinion last year that "money and scientific resources are being poured into attempts to make incremental progress at a time when there is an urgent need for disruptive change" (Usdin, 2019). We agree with this perspective, but would add that without proper investment in foundational understanding of the science and technology, efforts to innovate further engineered T-cell therapies are likely to bog down in frustrating unpredictability. Risk tolerance must be wedded to broad, deep preclinical datasets that enable better prediction of outcomes on the clinical frontier.

\section{Data availability}

No data is associated with this article.
Abramson JS: Anti-CD19 CAR T-Cell Therapy for B-Cell Non-Hodgkin Lymphoma. Transfus Med Rev. 2020; 34(1): 29-33.

PubMed Abstract | Publisher Full Text

Anderson DR, Grillo-López A, Varns C, et al.: Targeted anti-cancer therapy using rituximab, a chimaeric anti-CD20 antibody (IDEC-C2B8) in the treatment of non-Hodgkin's B-cell lymphoma. Biochem Soc Trans. 1997; 25(2): 705-8.

PubMed Abstract | Publisher Full Text

Bryceson YT, Long EO: Line of attack: NK cell specificity and integration of signals. Curr Opin Immunol. 2008; 20(3): 344-52.

PubMed Abstract | Publisher Full Text | Free Full Text

Buchdunger $\mathrm{E}$, Zimmermann J, Mett $\mathrm{H}$, et al.: Inhibition of the Abl proteintyrosine kinase in vitro and in vivo by a 2-phenylaminopyrimidine derivative. Cancer Res. 1996; 56(1): 100-4.

PubMed Abstract

Castella M, Caballero-Baños M, Ortiz-Maldonado V, et al.: Point-Of-Care CAR
T-Cell Production (ARI-0001) Using a Closed Semi-automatic Bioreactor: Experience From an Academic Phase I Clinical Trial. Front Immunol. 2020; 11: 482.

PubMed Abstract | Publisher Full Text | Free Full Text

Castle JC, Uduman M, Pabla S, et al.: Mutation-Derived Neoantigens for Cancer Immunotherapy. Front Immunol. 2019; 10: 1856. PubMed Abstract | Publisher Full Text | Free Full Text

Chamoto K, Hatae R, Honjo T: Current issues and perspectives in PD-1 blockade cancer immunotherapy. Int J Clin Oncol. 2020; 25(5): 790-800. PubMed Abstract | Publisher Full Text | Free Full Text

Committee of Revision and Publication of the Pharmacopoeia of the United States of America, United States Pharmacopœial Convention: The pharmacopœia of the United States of America. 8th decennial revision / [United States]: Board of Trustees. 1907

Reference Source

Cong L, Ann Ran F, Cox D, et al.: Multiplex genome engineering using 
CRISPR/Cas systems. Science. 2013; 339(6121): 819-23. PubMed Abstract | Publisher Full Text | Free Full Text

Courtney AH, Lo WL, Weiss A: TCR Signaling: Mechanisms of Initiation and Propagation. Trends Biochem Sci. 2018; 43(2): 108-123. PubMed Abstract | Publisher Full Text | Free Full Text

Desnoyers LR, Vasiljeva O, Richardson JH, et al.: Tumor-specific activation of an EGFR-targeting probody enhances therapeutic index. Sci Trans/ Med. 2013; 5(207): 207ra144.

PubMed Abstract | Publisher Full Text

Fedorov VD, Themeli M, Sadelain M: PD-1- and CTLA-4-based inhibitory chimeric antigen receptors (iCARs) divert off-target immunotherapy responses. Sci Transl Med. 2013; 5(215): 215 ra172.

PubMed Abstract | Publisher Full Text | Free Full Text

Fiorenza S, Ritchie DS, Ramsey SD, et al.: Value and affordability of CAR T-cell therapy in the United States. Bone Marrow Transplant. 2020 55(9): 1706-1715. PubMed Abstract | Publisher Full Text

Fisher B, Packard BS, Read EJ, et al.: Tumor localization of adoptively transferred indium-111 labeled tumor infiltrating lymphocytes in patients with metastatic melanoma. J Clin Oncol. 1989; 7(2): 250-61. PubMed Abstract | Publisher Full Text

Gross G, Waks T, Eshhar Z: Expression of immunoglobulin-T-cell receptor chimeric molecules as functional receptors with antibody-type specificity. Proc Natl Acad Sci U S A. 1989; 86(24): 10024-8.

PubMed Abstract | Publisher Full Text | Free Full Text

Gudmundsdottir $\mathrm{H}$, Wells AD, Turka LA: Dynamics and requirements of $\mathrm{T}$ cell clonal expansion in vivo at the single-cell level: effector function is linked to proliferative capacity. J Immunol. 1999; 162(9): 5212-23. PubMed Abstract

Guedan S, Ruella M, June CH: Emerging Cellular Therapies for Cancer. Annu Rev Immunol. 2019; 37: 145-171.

PubMed Abstract | Publisher Full Text | Free Full Text

Hamburger AE, DiAndreth B, Cui J, et al.: Engineered T cells directed at

tumors with defined allelic loss. Mol Immunol. 2020; 128: 298-310.

PubMed Abstract | Publisher Full Text

Hinrichs CS, Rosenberg SA: Exploiting the curative potential of adoptive

T-cell therapy for cancer. Immunol Rev. 2014; 257(1): 56-71.

PubMed Abstract | Publisher Full Text | Free Full Text

Janeway CA Jr, Travers P, Capra JD: Immunobiology: The Immune System in

Health and Disease. Garland Publishers, New York. 1999.

Reference Source

Jinek M, Chylinski K, Fonfara I, et al.: A programmable dual-RNA-guided DNA endonuclease in adaptive bacterial immunity. Science. 2012; 337(6096):

$816-2$.

PubMed Abstract | Publisher Full Text | Free Full Text

Kamb A: What's wrong with our cancer models? Nat Rev Drug Discov. 2005; 4(2): 161-5.

PubMed Abstract | Publisher Full Text

Locke FL, Go WY, Neelapu SS: Development and Use of the Anti-CD19

Chimeric Antigen Receptor T-Cell Therapy Axicabtagene Ciloleucel in Large

B-Cell Lymphoma: A Review. JAMA Oncol. 2020; 6(2): 281-290.

PubMed Abstract | Publisher Full Text

Lu YC, Parker LL, Lu T, et al: Treatment of Patients With Metastatic Cancer Using a Major Histocompatibility Complex Class II-Restricted T-Cell Receptor Targeting the Cancer Germline Antigen MAGE-A3. J Clin Oncol. 2017; 35(29): 3322-3329.

PubMed Abstract | Publisher Full Text | Free Full Text

Neelapu, et al:: ASCO. 2020b.

Neelapu SS, Jacobson CA, Oluwole OO, et al.: Outcomes of older patients in

ZUMA-1, a pivotal study of axicabtagene ciloleucel in refractory large

B-cell lymphoma. Blood. 2020a; 135(23): 2106-2109.

PubMed Abstract | Publisher Full Text | Free Full Text
Neelapu SS, Locke FL, Bartlett NL, et al:: Axicabtagene Ciloleucel CAR T-Cell Therapy in Refractory Large B-Cell Lymphoma. N EnglJ Med. 2017; 377(26): 2531-2544.

PubMed Abstract | Publisher Full Text | Free Full Text

Nemoto T, Takeshita T, Ishii N, et al.: Differences in the interleukin-2 (IL-

2) receptor system in human and mouse: alpha chain is required for

formation of the functional mouse IL-2 receptor. Eur J Immunol. 1995; 25(11):

3001-3005.

PubMed Abstract | Publisher Full Text

Nerreter T, Letschert S, Götz R, et al:: Super-resolution microscopy reveals ultra-low CD19 expression on myeloma cells that triggers elimination by CD19 CAR-T. Nat Commun. 2019; 10(1): 3137.

PubMed Abstract | Publisher Full Text | Free Full Text

$\mathrm{Ng} \mathrm{AHC}$, Peng S, Xu AM, et al:: MATE-Seq: microfluidic antigen-TCR engagement sequencing. Lab Chip. 2019; 19(18): 3011-3021.

PubMed Abstract | Publisher Full Text

Norberg S, Nagarsheth N, Sinkoe A, et al:: Safety and clinical activity of geneengineered T-cell therapy targeting HPV-16 E7 for epithelial cancers. J Clin Oncol. 2020; 38(15 suppl): 101

Publisher Full Text

Parkhurst MR, Yang JC, Langan RC, et al.: T cells targeting carcinoembryonic antigen can mediate regression of metastatic colorectal cancer but induce severe transient colitis. Mol Ther. 2011; 19(3):620-6.

PubMed Abstract | Publisher Full Text | Free Full Text

Roberts MR, Qin L, Zhang D, et al.: Targeting of human immunodeficiency virus-infected cells by CD8+ T lymphocytes armed with universal T-cell receptors. Blood. 1994; 84(9): 2878-89.

PubMed Abstract | Publisher Full Text

Rossi J, Paczkowski P, Shen YW, et al.: Preinfusion polyfunctional anti-CD19 chimeric antigen receptor $\mathrm{T}$ cells are associated with clinical outcomes in NHL. Blood. 2018; 132(8): 804-814.

PubMed Abstract | Publisher Full Text | Free Full Text

Roybal KT, Williams JZ, Morsut L, et al.: Engineering T Cells with Customized Therapeutic Response Programs Using Synthetic Notch Receptors. Cell. 2016: 167(2): 419-432 e16.

PubMed Abstract | Publisher Full Text | Free Full Text

Salter RD, Creswell P: Impaired assembly and transport of HLA-A and -B antigens in a mutant TxB cell hybrid. EMBO I. 1986; 5(5): 943-9. PubMed Abstract | Publisher Full Text | Free Full Text

Schuster SJ, Bishop MR, Tam CS, et al.: Tisagenlecleucel in Adult Relapsed or Refractory Diffuse Large B-Cell Lymphoma. N Engl J Med. 2019; 380(1): 45-56. PubMed Abstract | Publisher Full Text

Silbert S, Yanik GA, Shuman AG: How Should We Determine the Value of CAR T-Cell Therapy? AMAJ Ethics. 2019; 21(10): E844-851.

PubMed Abstract | Publisher Full Text

Takahashi K, Yamanaki S: Induction of pluripotent stem cells from mouse embryonic and adult fibroblast cultures by defined factors. Cell. 2006;

126(4): 663-76.

PubMed Abstract | Publisher Full Text

Usdin: Biocentury. 2019.

Vogelstein B, Papadopoulos N, Velculescu VE, et al.: Cancer genome landscapes. Science. 2013; 339(6127): 1546-58.

PubMed Abstract | Publisher Full Text | Free Full Text

Yron I, Wood Jr TA, Spiess J, et al: In vitro growth of murine T cells. V. The isolation and growth of lymphoid cells infiltrating syngeneic solid tumors. J Immunol. 1980; 125(1): 238-45.

PubMed Abstract

Yu J, Vodyanik MA, Smuga-Otto K, et al.: Induced pluripotent stem cell lines derived from human somatic cells. Science. 2007; 318(5858): 1917-20. PubMed Abstract | Publisher Full Text 


\section{Open Peer Review}

\section{Current Peer Review Status:}

\section{Version 2}

Reviewer Report 04 January 2021

https://doi.org/10.5256/f1000research.31447.r76353

(C) 2021 Sasu B. This is an open access peer review report distributed under the terms of the Creative Commons Attribution License, which permits unrestricted use, distribution, and reproduction in any medium, provided the original work is properly cited.

\section{Barbra J. Sasu \\ Allogene Therapeutics, Inc.,, San Francisco, CA, USA}

I think that the revised version makes the author's intent in writing the review much more clear and is a valuable perspective.

One small comment that I would suggest is changing the C. June and P. Greenberg mention: 'nextgeneration CAR-Ts' to 'CAR-Ts and TCR-Ts' to more accurately describe Greenberg's work.

Competing Interests: No competing interests were disclosed.

Reviewer Expertise: T cell biology, CAR T

I confirm that I have read this submission and believe that I have an appropriate level of expertise to confirm that it is of an acceptable scientific standard.

Reviewer Report 04 January 2021

\section{https://doi.org/10.5256/f1000research.31447.r76354}

(C) 2021 James J et al. This is an open access peer review report distributed under the terms of the Creative Commons Attribution License, which permits unrestricted use, distribution, and reproduction in any medium, provided the original work is properly cited.

\section{John R. James}

Warwick Medical School, University of Warwick, Coventry, UK

Muna Fuyal

School of Life Sciences, University of Warwick, Coventry, UK

The authors have done a good job responding to all the comments of the reviewers, and so we are 
happy to approve the article.

Competing Interests: No competing interests were disclosed.

Reviewer Expertise: T cell signalling, signal transduction, reductionist approaches, Synthetic biology

We confirm that we have read this submission and believe that we have an appropriate level of expertise to confirm that it is of an acceptable scientific standard.

Reviewer Report 23 December 2020

\section{https://doi.org/10.5256/f1000research.31447.r76355}

(c) 2020 Begley C. This is an open access peer review report distributed under the terms of the Creative Commons Attribution License, which permits unrestricted use, distribution, and reproduction in any medium, provided the original work is properly cited.

\section{Glenn Begley}

BioCurate, Parkville, Vic, Australia

Thank you for noting my comments. I have nothing further to add.

Competing Interests: No competing interests were disclosed.

Reviewer Expertise: Translational research - oncology

I confirm that I have read this submission and believe that I have an appropriate level of expertise to confirm that it is of an acceptable scientific standard.

\section{Version 1}

Reviewer Report 02 December 2020

https://doi.org/10.5256/f1000research.30072.r74926

(c) 2020 Begley C. This is an open access peer review report distributed under the terms of the Creative Commons Attribution License, which permits unrestricted use, distribution, and reproduction in any medium, provided the original work is properly cited.

\section{Glenn Begley}

${ }^{1}$ BioCurate, Parkville, Vic, Australia

2 BioCurate, Parkville, Vic, Australia 
This review highlights the success of the recent advances in immune-oncology focusing particularly on cellular therapies, and outlines some of the fundamental scientific criteria that have been 'by-passed' in moving into the clinic, but that will likely need to be understood to make the cell-therapy approach applicable to solid tumors.

I note the valuable comments of James et al., and in addition suggest:

1. As part of the "revolution in immune-oncology" seen with checkpoint inhibitors, CAR-T cells, the authors should acknowledge another 'recombinant cellular therapy' - oncolytic viruses.

2. The authors are appropriately critical of mouse models that "trade off tractability with relevance" and are then "often regarded as decisive in selection of clinical candidates because of presumptive experimental supremacy. In our view this is specious." I agree completely! However given the ubiquity of these models regardless of therapeutic modality, it could be helpful to provide additional commentary as to how these models should be appropriately exploited.

Is the topic of the opinion article discussed accurately in the context of the current literature?

Partly

Are all factual statements correct and adequately supported by citations? Yes

Are arguments sufficiently supported by evidence from the published literature? Partly

Are the conclusions drawn balanced and justified on the basis of the presented arguments? Yes

Competing Interests: No competing interests were disclosed.

Reviewer Expertise: Translational research - oncology

I confirm that I have read this submission and believe that I have an appropriate level of expertise to confirm that it is of an acceptable scientific standard.

Author Response 14 Dec 2020

\section{Alexander Kamb}

1. As part of the "revolution in immune-oncology" seen with checkpoint inhibitors, CAR-T cells, the authors should acknowledge another 'recombinant cellular therapy' oncolytic viruses.

Our focus is on T-cell therapies, and not intended as an inclusive review. We have added "An opinion" to the title to clarify this. We acknowledge the interest of oncolytic viruses but do not see an unobtrusive way to feather them into our opinion piece. 
2. The authors are appropriately critical of mouse models that "trade off tractability with relevance" and are then "often regarded as decisive in selection of clinical candidates because of presumptive experimental supremacy. In our view this is specious." I agree completely! However given the ubiquity of these models regardless of therapeutic modality, it could be helpful to provide additional commentary as to how these models should be appropriately exploited.

We appreciate this comment, and now include a statement about xenograft models as an example: As a T-cell therapy example, simple xenograft models demonstrate that therapeutic function is compatible with the environment of a mammalian body; nothing more, but nothing less.

Competing Interests: No competing interests were disclosed.

Reviewer Report 30 November 2020

https://doi.org/10.5256/f1000research.30072.r74214

(C) 2020 Sasu B. This is an open access peer review report distributed under the terms of the Creative Commons Attribution License, which permits unrestricted use, distribution, and reproduction in any medium, provided the original work is properly cited.

\section{Barbra J. Sasu}

${ }^{1}$ Allogene Therapeutics, Inc.,, San Francisco, CA, USA

2 Allogene Therapeutics, Inc.,, San Francisco, CA, USA

The review deals with an important topic in T cell therapy - the use of appropriate methodology to increase mechanistic understanding and hopefully, eventually, translatability to the clinic.

At the outset, the authors quote some pioneers in the field of T cell and CAR therapy. Although it's not possible to add everyone, I would suggest that the addition of Phil Greenberg for his long history of pioneering work on TCR T cells and understanding how to apply engineering to these cells. Perhaps also Mike Jensen and Carl June for understanding the nature of first and second gen CAR T and scientists such as Malcolm Brenner for insights into competitive expansion of CARs in vivo are some suggestions for additions.

Analogy between development of SM and T cell therapeutics is an interesting comparison. Text in diagram should perhaps be bigger and QSAR needs to be defined in the legend.

The paragraph about building PD or mechanistic assays in the same spirit as the SM field is valuable but could be fleshed out more. E.g. The authors comment correctly that most work has to be done with primary cells since Jurkat unable to kill or behave in many other ways like normal T cells. There is reference to heterogeneousness, but perhaps calling out specifically that there is large donor to donor variability would be valuable.

Adding to in vivo model difficulties I might talk about mouse cytokine environment not supporting 
human cells without model modification and in syngeneic models, inherent difficulties between human and mouse T cells such as the need for different signaling strengths.

When pointing out shortcomings of screening approaches, say it needs to be more mechanistic. Some for instances might be useful, perhaps discussing possibilities for assays that might apply to parts of diagram 2, rather than the traditional endpoints in the T cell field of cytokine secretion, exhaustion markers or killing. Comments that in vivo assay can't deal with high throughput of candidates is true, but there is the potential for rapid in vivo assay to potentially look at certain aspects covered in diagram e.g. migration, activation, specificity that are hard to cover in vitro. Perhaps a compare on contrast on this would be useful.

Highlight other potential approaches to increasing tuor specificity e.g. synthetic biology from Wendel Lim or masking would be useful rather than just outlining one approach.

Quotes that cell therapy doses can exceed 100 billion cells - seems like an outlier and more normal ranges should be quoted both for CARs and TCRs, especially in light of the table comparing CARs and TCRs and in fact cell dose could be added to this table.

It was unclear to me if the table is meant to state dogma or the belief of authors. Some of the assumptions already have data challenging them and discussing some of this as a 'start of the journey' may be valuable, for example that CARs show good combination with PD-1 Abs in preclinical models.

At the end, the authors make strong statements that better assays are needed, which I can't argue with. Perhaps compare and contrast some assays and say what areas merit more development would be good. Potentials for solutions would make this review more valuable and might stimulate some of the general advances in the field that the review calls for. The review deals with an important topic in T cell therapy - the use of appropriate methodology to increase mechanistic understanding and hopefully, eventually, translatability to the clinic.

At the outset, the authors quote some pioneers in the field of T cell and CAR therapy. Although it's not possible to add everyone, I would suggest that the addition of Phil Greenberg for his long history of pioneering work on TCR T cells and understanding how to apply engineering to these cells. Perhaps also Mike Jensen and Carl June for understanding the nature of first- and secondgen CAR T and scientists such as Malcolm Brenner for insights into competitive expansion of CARs in vivo are some suggestions for additions.

Analogy between development of SM and T cell therapeutics is an interesting comparison. Text in diagram should perhaps be bigger and QSAR needs to be defined in the legend.

Highlight other potential approaches to increasing tuor specificity e.g. synthetic biology from Wendel Lim or masking would be useful rather than just outlining one approach.

Quotes that cell therapy doses can exceed 100 billion cells - seems like an outlier and more normal ranges should be quoted both for CARs and TCRs, especially in light of the table comparing CARs and TCRs and in fact cell dose could be added to this table.

It was unclear to me if the table is meant to state dogma or the belief of authors. Some of the 
assumptions already have data challenging them and discussing some of this as a 'start of the journey' may be valuable, for example that CARs show good combination with PD-1 Abs in preclinical models.

At the end, the authors make strong statements that better assays are needed, which I can't argue with. Perhaps compare and contrast some assays and say what areas merit more development would be good. Potentials for solutions would make this review more valuable and might stimulate some of the general advances in the field that the review calls for.

Is the topic of the opinion article discussed accurately in the context of the current literature?

Partly

Are all factual statements correct and adequately supported by citations?

Partly

Are arguments sufficiently supported by evidence from the published literature? Partly

Are the conclusions drawn balanced and justified on the basis of the presented arguments? Partly

Competing Interests: No competing interests were disclosed.

Reviewer Expertise: T cell biology, CAR T

I confirm that I have read this submission and believe that I have an appropriate level of expertise to confirm that it is of an acceptable scientific standard, however I have significant reservations, as outlined above.

Author Response 14 Dec 2020

Alexander Kamb

At the outset, the authors quote some pioneers in the field of T cell and CAR therapy. Although it's not possible to add everyone, I would suggest that the addition of Phil Greenberg for his long history of pioneering work on TCR T cells and understanding how to apply engineering to these cells. Perhaps also Mike Jensen and Carl June for understanding the nature of first and second gen CAR T and scientists such as Malcolm Brenner for insights into competitive expansion of CARs in vivo are some suggestions for additions.

We have mentioned Drs. Greenberg and June in the revision, but ask the reviewer to bear in mind that this is an opinion or perspective, not a review. We have added "An opinion" to the title to clarify this.

Analogy between development of SM and T cell therapeutics is an interesting comparison. Text in diagram should perhaps be bigger and QSAR needs to be defined in the legend.

We have defined QSAR and requested the additional change in size. 
The paragraph about building PD or mechanistic assays in the same spirit as the SM field is valuable but could be fleshed out more. E.g. The authors comment correctly that most work has to be done with primary cells since Jurkat unable to kill or behave in many other ways like normal T cells. There is reference to heterogeneousness, but perhaps calling out specifically that there is large donor to donor variability would be valuable.

We have included text to call this variability out specifically: ....with considerable donor-to-donor variability;

Adding to in vivo model difficulties I might talk about mouse cytokine environment not supporting human cells without model modification and in syngeneic models, inherent difficulties between human and mouse $T$ cells such as the need for different signaling strengths.

We have added text to highlight this specific problem (i.e., the mismatch between mouse/human cytokine signaling that can be understood partly as divergence between ligands and receptor pairs over 90 million years of evolutions (e.g., IL-2 ligand and receptor): The human and mouse components of these chimeras, e.g., IL-2 and IL2R, do not mesh perfectly (Nemoto et al., 1995).

When pointing out shortcomings of screening approaches, say it needs to be more mechanistic. Some for instances might be useful, perhaps discussing possibilities for assays that might apply to parts of diagram 2, rather than the traditional endpoints in the T cell field of cytokine secretion, exhaustion markers or killing. Comments that in vivo assay can't deal with high throughput of candidates is true, but there is the potential for rapid in vivo assay to potentially look at certain aspects covered in diagram e.g. migration, activation, specificity that are hard to cover in vitro. Perhaps a compare on contrast on this would be useful.

We agree with the reviewer and have pointed out the need to study certain aspects of T-cell biology in vivo, comparing mechanisms that can be studied in vitro with those that require in vivo experimentation. We have added to the legend of Fig. 2 a comment about the need for more mechanistic information.: This diagram illustrates the number and complexity of the steps required to achieve efficacy. Many of these steps can be studied in vitro; for others (e.g., extravasation), in vitro models are inherently problematic.

Highlight other potential approaches to increasing tuor specificity e.g. synthetic biology from Wendel Lim or masking would be useful rather than just outlining one approach. We have mentioned the SynNotch approach of Dr. Lim and colleagues, (Williams et al., 2020). We have also referenced ligand-binding domain masking approaches and added one reference (Desnoyers et al., 2013): Other approaches are under study, including transcriptional logic circuits and receptor masking (Roybal et al., 2016; Desnoyers et al., 2013). These attempts to widen the target source for selective cancer targets to other targets, including neoantigens and $\mathrm{LOH}, .$.

Quotes that cell therapy doses can exceed 100 billion cells - seems like an outlier and more normal ranges should be quoted both for CARs and TCRs, especially in light of the table comparing CARs and TCRs and in fact cell dose could be added to this table. 
We have added a range of T-cell therapeutic doses and altered the sentence: ...range from 100 million to 100 billion cells-well beyond the number...

It was unclear to me if the table is meant to state dogma or the belief of authors. Some of the assumptions already have data challenging them and discussing some of this as a 'start of the journey' may be valuable, for example that CARs show good combination with PD-1 Abs in preclinical models.

We have changed the title of the legend and added a clause that states: Potential differences among cell therapy targets, receptors, and regulation not yet rigorously tested by mechanistic data. Experiments to test many of these assumptions are underway.

At the end, the authors make strong statements that better assays are needed, which I can't argue with. Perhaps compare and contrast some assays and say what areas merit more development would be good. Potentials for solutions would make this review more valuable and might stimulate some of the general advances in the field that the review calls for. The review deals with an important topic in T cell therapy - the use of appropriate methodology to increase mechanistic understanding and hopefully, eventually, translatability to the clinic.

We make general statements about the kind of assays, but have added text indicating that sensitivity in particular is a useful parameter to measure because it provides a connection among different targets and receptors: In particular, we believe that quantitative assays that measure absolute sensitivity of receptors should be more widely employed, allowing direct comparisons among different targets and receptors.

Competing Interests: No competing interests were disclosed.

Reviewer Report 17 November 2020

https://doi.org/10.5256/f1000research.30072.r74217

(c) 2020 James J et al. This is an open access peer review report distributed under the terms of the Creative Commons Attribution License, which permits unrestricted use, distribution, and reproduction in any medium, provided the original work is properly cited.

John R. James

1 Warwick Medical School, University of Warwick, Coventry, UK

2 Warwick Medical School, University of Warwick, Coventry, UK

Muna Fuyal

1 School of Life Sciences, University of Warwick, Coventry, UK

2 School of Life Sciences, University of Warwick, Coventry, UK

The review article from Kamb and Go provides an overview of how T-cell based therapies are being used in cancer treatment. The challenges arising from this approach and how the 
foundation of T-cell therapy research can be built for development of more potent treatment of solid tumours are discussed. Their main point is that in the rush to get CAR-T therapy to patients, some of the underlying foundational research has been bypassed, which needs to be 'filled in' so the potential benefits of T-cell therapies can be fully realised, which is of course an important concern to raise.

There are a few points that should be addressed to improve this version of the manuscript: The paper would be clearer if the authors could inform about the distinct challenges of CAR$T$ therapy used for treating blood cancers compared to those of solid tumours. At times, the information is overlapped and slightly unclear.

In the early discussion of significant players in the CAR-T field, it is remiss not to state the contribution of Carl June's lab. While much of his group's work has primarily been in leukaemia rather than solid tumours, it has nonetheless provided real impetus that this approach could be transformational in cancer therapies.

There is a slight pessimism to the state of knowledge on the mechanism of TCR triggering; while no true consensus will ever be reached on this question, there is little doubt that the fundamental aspects of this signal transduction have been elucidated.

The authors compare the state-of-the-art development of small-molecule drugs to the equivalent process for T-cell based therapies. They argue that mouse models are not appropriate tools to study (human) immuno-oncology, which is of course strictly true but a charge that can be just as easily levelled at small-molecule drug approaches too and so perhaps unfair for T-cell therapies to be singled out.

There is no mention of BiTE or ImmTAC therapeutics as alternative T-cell based therapies, which do have potentially greater likelihood of being effective in treating solid tumour masses.

The authors have listed four additional requirements for effective and safe solid tumour therapy (page 5 under heading Additional challenges for T-cell therapy) along with identifying drug target. The review could do well with more information on these listed points such as current research being carried out to address these limitations.

There are many labs around the world trying to combine engineering approaches to provide 'logic-gating' to CAR-T cell targeting. As the authors state, targets are hard to come by, but the potential for combinatorial CAR-T inputs (AND/NAND/NOT gating) significantly extends the usefulness of some likely targets to more accurately define solid tumour targets.

Table 1 describes some commonly-held assumptions about T-cell therapies "not yet rigorously tested by mechanistic data". The authors do provide a basis for these assumptions but no references to back these up. Whose "commonly held assumptions" are they?

The authors state: "This foundation-building work may not be glamorous but is of great consequence and should be valued by scientific journals. If the field as a whole invests to 
build the infrastructure and expertise of better preclinical models and larger datasets and allocates time to define key mechanistic details prior to clinical testing, we believe the risks required to develop inventive, differentiated therapies will be rewarded with success." This point should be elaborated on to explain the roles of pharmaceutical companies, scientists and research institutes. Who takes the "unglamourous" job of foundation building? We would argue that academia is taking these risks and doing the foundational work; perhaps the point is aimed more at Pharma that they should also invest more heavily in this work too?

Is the topic of the opinion article discussed accurately in the context of the current literature?

Partly

Are all factual statements correct and adequately supported by citations? Partly

Are arguments sufficiently supported by evidence from the published literature? Partly

Are the conclusions drawn balanced and justified on the basis of the presented arguments? Partly

Competing Interests: No competing interests were disclosed.

Reviewer Expertise: T cell signalling, signal transduction, reductionist approaches, Synthetic biology

We confirm that we have read this submission and believe that we have an appropriate level of expertise to confirm that it is of an acceptable scientific standard, however we have significant reservations, as outlined above.

Author Response 14 Dec 2020

Alexander Kamb

We thank the reviewers for their constructive comments and believe they have understood our key point. We have attempted to address most of the reviewers' suggestions in the planned revised publication. We point out that we intend our paper to be an opinion or perspective, and not a review. Consequently, we have limited some of the references and discussion.

The paper would be clearer if the authors could inform about the distinct challenges of CAR-T therapy used for treating blood cancers compared to those of solid tumours. At times, the information is overlapped and slightly unclear.

We agree and have added text to clarify the specific challenges of solid tumors. Perhaps most dramatically, infused T-cell therapeutics directed against solid tumors must extravasate to reach their targets, targets that may be present on a subset of vital normal tissues as well. 
In the early discussion of significant players in the CAR-T field, it is remiss not to state the contribution of Carl June's lab. While much of his group's work has primarily been in leukaemia rather than solid tumours, it has nonetheless provided real impetus that this approach could be transformational in cancer therapies.

We agree and have included Dr. June's name and referenced his contributions. Still others have made substantive contributions to understanding, design and development of next-generation CAR-Ts; for example, C. June and P. Greenberg (see for review Guedan et al., 2019).

There is a slight pessimism to the state of knowledge on the mechanism of TCR triggering; while no true consensus will ever be reached on this question, there is little doubt that the fundamental aspects of this signal transduction have been elucidated.

We do not intend pessimism, and have clarified our view that, though important basic mechanistic questions remain (e.g., altered-peptide ligands, APLs), the TCR and CAR signaling mechanisms are understood in outline at least (a good example is the work of Dr. James): For example, there is not a broadly accepted model that explains key behavior of TCRs with respect to sensitivity and selectivity toward their ligands, peptide major histocompatibility complexes (pMHCs). CAR signaling, though understood in outline, also lacks important details (see for review Courtney et al., 2018; Nerreter et al., 2019).

The authors compare the state-of-the-art development of small-molecule drugs to the equivalent process for T-cell based therapies. They argue that mouse models are not appropriate tools to study (human) immuno-oncology, which is of course strictly true but a charge that can be just as easily levelled at small-molecule drug approaches too and so perhaps unfair for T-cell therapies to be singled out.

We agree wholeheartedly and have clarified this point: These deficits apply to small- and large-molecule therapeutic discovery.

There is no mention of BiTE or ImmTAC therapeutics as alternative T-cell based therapies, which do have potentially greater likelihood of being effective in treating solid tumour masses.

We know these modalities well, but believe that cell therapy holds more promise for solid tumor therapies. Cells can be engineered, if they do not do so already, to distribute into tissues. Large molecules (soluble proteins) are much more limited in what they can be engineered to do, beyond binding things, and are constrained by their physico-chemical properties.

The authors have listed four additional requirements for effective and safe solid tumour therapy (page 5 under heading Additional challenges for T-cell therapy) along with identifying drug target. The review could do well with more information on these listed points such as current research being carried out to address these limitations. We should be clear that we do not intend to review the topic; our publication is more properly classified as an opinion piece. These topics are beyond the scope of our paper, and there are numerous reviews in the literature. 
There are many labs around the world trying to combine engineering approaches to provide 'logic-gating' to CAR-T cell targeting. As the authors state, targets are hard to come by, but the potential for combinatorial CAR-T inputs (AND/NAND/NOT gating) significantly extends the usefulness of some likely targets to more accurately define solid tumour targets.

We have added a sentence to emphasize this point; i.e., that there are other logic systems beyond the AND NOT logic we describe in brief: Other approaches are under study, including transcriptional logic circuits and receptor masking (Roybal et al., 1995; Desnoyers et al., 2013). These attempts to widen the target source for selective cancer targets to other targets, including neoantigens and LOH...

Table 1 describes some commonly-held assumptions about T-cell therapies "not yet rigorously tested by mechanistic data". The authors do provide a basis for these assumptions but no references to back these up. Whose "commonly held assumptions" are they?

We encounter people with different subsets of these assumptions frequently, but it is difficult to provide a suitable reference. We have changed the wording of the Table 1 title and in the text: There are many potential differences between, for example, TCRs and CARs which have not been tested systematically, and the field would benefit from their thorough examination (Table 1). We are certainly open to alternative phrasing.

The authors state: "This foundation-building work may not be glamorous but is of great consequence and should be valued by scientific journals. If the field as a whole invests to build the infrastructure and expertise of better preclinical models and larger datasets and allocates time to define key mechanistic details prior to clinical testing, we believe the risks required to develop inventive, differentiated therapies will be rewarded with success." This point should be elaborated on to explain the roles of pharmaceutical companies, scientists and research institutes. Who takes the "unglamourous" job of foundation building? We would argue that academia is taking these risks and doing the foundational work; perhaps the point is aimed more at Pharma that they should also invest more heavily in this work too?

We strongly agree that there should be investment in foundation-building academic research by granting agencies, and have added this opinion explicitly: Our strong view is that granting agencies should invest in foundation-building academic research, in part because shorter-term translational work is often attractive to the private sector.

Competing Interests: No competing interests were disclosed. 
The benefits of publishing with F1000Research:

- Your article is published within days, with no editorial bias

- You can publish traditional articles, null/negative results, case reports, data notes and more

- The peer review process is transparent and collaborative

- Your article is indexed in PubMed after passing peer review

- Dedicated customer support at every stage

For pre-submission enquiries, contact research@f1000.com 